\title{
FUNGICIDE, ADJUVANT AND LIME FOR CONTROL OF CLUBROOT OF BRASSICAS
}

\author{
L-H. CHEAH and B.B.C. PAGE \\ Institute for Crop \& Food Research Limited, Private Bag 11600, Palmerston North
}

A field trial to evaluate two soil fungicides (fluazinum and flusulfamide in five treatments) combined with high soil pH (7.0) was established at a Levin grower's property on land known to be heavily infested with clubroot disease. Hydrated lime was added to the plot soil to increase the soil $\mathrm{pH}$ from 6.3 to 7.0. Fungicide suspensions were prepared to the required concentrations and sprayed onto the soil surface of each plot. The plots were rotary hoed to a depth of about $12 \mathrm{~cm}$ to incorporate chemical into the soil. Chinese cabbage (Wong-Bok) seedlings were then transplanted into the trial plots. All fungicide treatments (fluazinum @ $1.5 \mathrm{~kg}$ and $2.0 \mathrm{~kg} / \mathrm{ha}$, flusulfamide @ 0.6 $\mathrm{kg}$ and $0.9 \mathrm{~kg} / \mathrm{ha}$ and flusulfamide soil drench @ $0.9 \mathrm{mg}$ per plant) significantly $(\mathrm{P}=0.05)$ reduced the clubroot score on root systems and increased the top weight of the plant compared to the untreated control. Soil drench with flusulfamide plus adjuvant (Silwet @ 0.1\%) gave almost complete (97\%) control of the disease but caused some leaf burn. High soil pH did not contribute to the control of the disease or increase the top weights.

\section{WEEDS ARE IMPORTANT SOURCES OF POTYVIRUS INFECTION IN BUTTERCUP SQUASH CROPS}

\author{
J.D. FLETCHER and T.J.B. HERMAN
}

\section{New Zealand Institute for Crop \& Food Research, Private Bag 4704, Christchurch}

Zucchini yellow mosaic (ZYMV) and watermelon mosaic 2 (WMV2) potyviruses cause yield and quality losses in New Zealand buttercup squash crops. Weeds at Hawke's Bay sites where squash had been grown previously were surveyed early in spring. At one site closely monitored for three seasons, weed and squash specimens were collected, identified and tested for viruses using ELISA and indicator inoculations. Associated aphids were also collected and identified. Weeds infected with WMV2 or ZYMV included: black nightshade, broad-leaved dock, broad-leaved plantain, chickweed, cleavers, fathen, fennel, field madder, hawks beard, hemlock, horehound, lily of the valley vine, mallow, oxtongue, rayless chamomile, redroot, scrambling spellweed, sow thistle, staggerweed, subclover, twin cress, vetch, wavy-leaved fleabane, white clover, wild carrot and wild turnip. Aphids recorded as vectors of WMV2 or ZYMV found on these weeds included: melon, green peach, pea, black legume, glasshouse/foxglove potato, carrot willow, cereal, potato, turnip, thistle, leaf-curling plum, lettuce, and rose aphids. Between 30-70\% of surveyed crops had mosaic symptoms over the three seasons. WMV2 prevailed with ZYMV present in only four crops with 1$6 \%$ incidence. Mosaic incidence increased sequentially over the three years, reaching $70 \%$ in squash and pumpkin crops, with infections initiating from nearby virus infected weeds. Highest incidences of virus occurred during 1997-8 when high aphid numbers were recorded. We conclude that weeds act as important reservoirs for the initiation of potyvirus diseases of buttercup squash in Hawke's Bay. 